\title{
Динамика показателей плазменного звена гемостаза под действием внутривенного лазерного облучения крови при внебольничной пневмонии
}

Кафедра терапии с общей врачебной практикой (семейной медициной) факультета последипломного и дополнительного образования Северо-Осетинской государственной медицинской академии: 362019, Россия, Республика Северная Осетия - Алания, Владикавказ, ул. Пушкинская, 40

\section{N.M.Burduli, N.G.Pilieva \\ Effects of low-intensity laser therapy on hemostasis in patients with community-acquired pneumonia}

\begin{abstract}
Summary
The aim of this study was to investigate effects of laser therapy on protein $\mathrm{C}$ and other parameters of blood coagulation in patients with community-acquired pneumonia (CAP). One hundred and forty patients with CAP were randomly divided into two groups. Of them, 100 patients received conventional chemotherapy and laser irradiation (the study group) and 40 patients were treated with chemotherapy only (the control group). In the study group, there was a significant improvement in protein $\mathrm{C}$ system and hypercoagulation. Thus, the laser therapy is an effective method for treatment of CAP and could be recommended in relevant combined regimens.

Key words: protein C, laser therapy, hypercoagulation, community-acquired pneumonia.
\end{abstract}

\section{Резюме}

Целью исследования было изучение активности системы протеина С и других показателей гемостаза под влиянием внутривенного лазерного облучения крови (ВЛОК) у пациентов с внебольничной пневмонией (ВП). Были обследованы 140 больных ВП в возрасте от 17 до 62 лет (средний возраст - 39,5 \pm 8,4 года). Больным контрольной группы (40 человек) назначалась традиционная медикаментозная терапия, пациенты основной группы (100 человек) в дополнение к традиционной терапии получали курс ВЛОК. У больных ВП до лечения отмечается снижение активности системы протеина С, явления гиперкоагуляции, которые устраняются при использовании ВЛОК. Таким образом, ВЛОК является эффективным методом коррекции нарушений гемокоагуляции у больных ВП.

Ключевые слова: протеин С, гемостаз, внутривенная лазерная терапия, внебольничная пневмония.

Наблюдающийся в последние годы неуклонный рост числа больных с неспецифическими заболеваниями легких обусловливает все возрастающее внимание клиницистов к проблеме ранней диагностики и лечения этих болезней. Одно из ведущих мест среди неспецифических заболеваний легких, как по тяжести прогноза, так и по частоте, занимает пневмония. На сегодняшний день пневмония относиться к числу распространенных нозологических форм и занимает 4-е место в структуре смертности в развитых странах [1].

При развитии пневмонии нереспираторная, гипокоагулирующая функция легких нарушается, наблюдаются изменения гемокоагуляции, свидетельствующие в основном о повышении свертываемости крови. Повышенная коагуляция крови определяет выраженные нарушения во внутрисосудистом звене микроциркуляции и способствует развитию ДВСсиндрома (синдрома диссеминированного внутрисосудистого свертывания крови), что в совокупности является причиной каскадного формирования микротромбов в системе легочной артерии, блокады кровообращения в очаге воспаления, приводящих к затяжному течению пневмонии и создающих благоприятные условия для размножения бактерий.
В развитии патологии гемостаза ведущим фактором является нарушение равновесия между свертывающей и противосвертывающей системами крови. Значительная роль в противосвертывающем потенциале крови принадлежит физиологическим антикоагулянтам: системе "антитромбин III - гепарин", $\alpha_{2}$-макроглобулину, кофактору II гепарина, системе комплемента, а также открытой в последнее время уникально тонкой антикоагулянтной системе протеина С [2-5]. Протеин С - это белок плазмы, который является ключевым компонентом естественной системы антикоагуляции. Этот факт был известен достаточно давно, однако в последнее время появился ряд доказательств, указывающих на то, что протеин С играет важную роль и в противовоспалительной системе. Воздействие протеина С на воспалительный процесс реализуется через следующие механизмы:

- система протеина С снижает присоединение селектинов к лейкоцитам, что сопровождается сохранением цельности сосудистого эндотелия, играющего важную роль в развитии воспалительного процесса;

- снижает высвобождение цитокинов из моноцитов; 
• ингибирует выработку тромбина, который потенцирует воспалительный ответ.

Большая значимость для противосвертывающего и противовоспалительного потенциала крови и малая изученность в пульмонологической практике определяют актуальность исследования этого антикоагулянта у больных внебольничной пневмонией (ВП).

С целью выявления и изучения динамики нарушений в плазменном звене системы гемостаза при ВП был проведен анализ активности системы протеина С и других показателей гемореологии до и после проведенного стационарного лечения. В качестве метода коррекции выявленных нарушений использовался курс внутрисосудистого лазерного облучения крови (ВЛОК).

\section{Материал и методы}

Были обследованы 140 больных ВП в возрасте от 17 до 62 лет (средний возраст - 39,5 \pm 8,4 года), из них 96 пациентов (68,6 \%) - мужчины, 44 (31,4 \%) - женщины. Диагностика ВП базировалась на традиционной схеме [1]. В исследование не включались пациенты с пневмонией крайне тяжелого течения, осложненной деструкцией легочной ткани, а также больные с тяжелой сопутствующей патологией. Все пациенты были разделены на 2 группы: контрольную (40 человек) и основную (100 человек). Больные контрольной группы получали традиционное комплексное лечение, основу которого составляли антибактериальные препараты, кроме того, применялись отхаркивающие, муколитические средства, по показаниям - симптоматическая терапия. Больным основной группы дополнительно к традиционной терапии проводился курс ВЛОК.

Курс ВЛОК состоял из 10 ежедневных сеансов длительностью до 20 мин. Облучение крови производилось через 1-разовые внутривенные световоды с применением полупроводникового аппарата "Мулат" ("НПО Космического приборостроения", Россия) с мощностью излучения 2 мВт, длиной волны 630 нм. Суммарная доза облучения составляла 2-2,5 Дж.

Активность системы протеина С определялась скрининговым методом и выражалась в виде нормализованного отношения (НО) [2]. Исследование гуморального звена системы свертывания крови проводилось путем определения антитромбина III (AT III), тромбинового времени (ТВ), протромбино-

вого времени (ПВ), активированное частичное тромбопластиновое время (АЧТВ). Все исследования проводились по стандартным методикам с применением коагулометра CGL 2110 ("Солар", Беларусь). Разработчик и изготовитель всех используемых реактивов - НПО "Ренам" (Россия).

Статистическая обработка результатов исследования проводилась с использованием пакета статистических программ Microsoft Excel 2000. Все данные представлены в виде $M \pm m$. Достоверность различий между группами определялась по критерию Стьюдента при $p<0,05$.

\section{Результаты и обсуждение}

При исследовании показателей плазменного звена гемостаза у большинства больных ВП до лечения отмечались гиперкоагуляционные сдвиги (таблица). Это проявлялось в снижении противосвертывающего потенциала крови, а именно в подавлении активности системы протеина С и АТ III. Кроме того, у обследуемых больных при сравнении с нормой наблюдалось укорочение АЧТВ как в основной, так и в контрольной группе. У пациентов обеих групп регистрировалось статистически значимое снижение ПВ и ТВ в контрольной и основной группах.

Таким образом, повреждение легочной ткани при ВП ведет к нарушению процессов гемокоагуляции. Включение в патогенетическое звено гиперкоагуляционных изменений крови при ВП способствует развитию стаза крови, изменению биоэлектрических зарядов в сосудистой стенке, повышению агрегационных свойств форменных элементов крови, микротромбированию и запустеванию капиллярного русла малого круга кровообращения. В связи с этим весьма актуальным является применение ВЛОК в комплексной терапии больных ВП.

Сравнительная характеристика показателей гемостаза после проведенного лечения представлена в таблице. В группе больных, получавших лазерную терапию, после лечения отмечается повышение активности системы протеина С до $0,994 \pm 0,02$, что достоверно выше исходного уровня $(p<0,05)$. Для установления зависимости между активностью системы протеина С и клиническими признаками пневмонии нами проведен корреляционный анализ, в результате которого выявлена сильная обратная корреляционная связь между уровнем протеина С (HО) и тяжестью клинического состояния больных

Таблица

Показатели гемокоагуляии у больных ВП в ходе проводимой терапии

\begin{tabular}{|c|c|c|c|c|c|}
\hline \multirow[t]{2}{*}{ Показатель } & \multirow[t]{2}{*}{ Норма } & \multicolumn{2}{|c|}{ Контрольная группа } & \multicolumn{2}{|c|}{ Основная группа } \\
\hline & & до лечения & после лечения & до лечения & после лечения \\
\hline АЧТВ, $c$ & $33,6 \pm 2,2$ & $27,3+1,1^{*}$ & $30,3 \pm 1,2$ & $26,7 \pm 1,2^{*}$ & $34,6 \pm 1,1^{* *}$ \\
\hline$\Pi B, C$ & $25,5 \pm 0,4$ & $19,2+1,0^{*}$ & $21,0 \pm 0,5^{*}$ & $20,5 \pm 1,03^{*}$ & $25,0 \pm 1,01^{* *}$ \\
\hline TB, C & $12,2 \pm 0,2$ & $11,3 \pm 0,9^{*}$ & $13,5 \pm 0,9$ & $10,4 \pm 0,1^{*}$ & $14,3 \pm 1,08^{* *}$ \\
\hline AT III, \% & $100 \pm 17,4$ & $88,6 \pm 1,3$ & $97,14 \pm 2,7$ & $86,3 \pm 2,8$ & $104,6 \pm 5,1$ \\
\hline Протеин С (НО) & $1,08 \pm 0,03$ & $0,617 \pm 0,04^{*}$ & $0,684 \pm 0,09$ & $0,614 \pm 0,03^{*}$ & $0,994 \pm 0,02^{* *}$ \\
\hline
\end{tabular}

Примечание: * $-p<0,05$ в сравнении с нормой; ** $-p<0,05$ в сравнении с исходным значением. 
$(r=-0,73)$. Согласно полученным данным, при снижении активности системы протеина С нарастает тяжесть клинического состояния. По мере нормализации клинического состояния больного происходит и нормализация активности системы протеина С, что свидетельствует о повышении противосвертывающего потенциала крови. Однако только применение в составе комплексной терапии ВЛОК (основная группа больных) способствует нормализации активности системы протеина С, т. к. в контрольной группе динамика этого показателя носила недостоверный характер (с 0,617 \pm 0,04 до 0,684 \pm 0,09; $p>0,05)$.

Динамика AT III в сравниваемых группах тоже значительно различалась. Так, у пациентов контрольной группы после проведенного лечения отмечалось незначительное $(p>0,05)$ повышение уровня AT III, в то время как в основной группе наблюдалось статистически достоверное повышение этого показателя до $101,6 \pm 8,1 \%$, что соответствует показателям в группе здоровых лиц.

ВЛОК способствовало нормализации и других параметров гуморального звена гемостаза. Так, если исходно у больных ВП отмечались явления гиперкоагуляции и усиления свертывающих свойств крови, то после лечения повышалось время свертывания крови на основных этапах тромбообразования, при этом в основной группе положительная динамика была выражена более четко и носила статистически достоверный характер. В основной группе происходит достоверная нормализация исходно ускоренного АЧТВ. В контрольной группе отмечается статистически не значимое возрастание этого показателя, которое не достигает уровня нормальных значений и после завершения стационарного этапа терапии. ПВ после проведенного лечения значительно отличается от исходного уровня $(20,5 \pm 1,03$ с) только в основной группе, где становится равным 25,0 1,01 с $(p<0,05)$, что соответствует норме. В то же время, в контрольной группе нормализации ПВ не происходит, и после завершения лечения оно составляет $21,0 \pm 0,5$ с. После проведенного курса терапии динамика ТВ также различна в зависимости от применяемых методов лечения: в основной группе происходит его возрастание до нормальных значений, тогда как в контрольной группе динамика ТВ весьма незначительна.

\section{Заключение}

Традиционная терапия ВП не сопровождается достоверным улучшением активности системы протеина $\mathrm{C}$ и других показателей гемокоагуляции, что свидетельствует о сохранении дисбаланса между свертывающей и противосвертывающей системами крови, следовательно, у этой категории больных высока вероятность развития различных тромбоэмболических осложнений, а также формирования затяжных форм бронхолегочной патологии. Нормализация процессов гемокоагуляции в группе пациентов, получавших ВЛОК, способствовала улучшению гемореологических параметров крови в целом. Кроме того, восстановление равновесия в системе регуляции агрегатного состояния крови у больных ВП под влиянием ВЛОК сопровождается улучшением клинической картины заболевания, снижением медикаментозной нагрузки на пациента, уменьшением длительности пребывания пациентов в стационаре.

\section{Литература}

1. Внебольничная пневмония у взрослых: Практические рекомендации по диагностике, лечению и профилактике. Пособие для врачей. / Чучалин А.Г., Синопальников А.И., Яковлев С.В. и др. Смоленск; 2003.

2. Берковский А.Л., Васильева С.А., Качалова Н.Д., Сергеева Е.В. Скрининговый тест на протеин. Клин. лаб. диагн. 2001; 3: 36-37.

3. Егорова В.В., Берковский А.Л., Сергеева Е.В. и др. Исследование нарушений антикоагулянтной системы протеина С при различных клинических состояниях. Клин. мед. 2000; 11: 46-50.

4. Ена Я.М., Платонова Т.Н., Сушко Е.А. и др. Биологическая роль и клиническое значение протеина С. Врач. дело 1992; 6: 20-24.

5. Москвин С.В., Азизов Г.А. Внутривенное лазерное облучение крови. М.: НПЛЦ "Техника"; 2003.

\section{Информация об авторах}

Бурдули Николай Михайлович - д. м. н., проф., зав. кафедрой терапии с общей врачебной практикой (семейной медициной) ФПДО СОГМА; тел.: (8672) 56-58-58, (8672) 53-42-21, факс (8672) 53-03-97

Пилиева Нана Гурамовна - ассистент кафедры терапии с общей врачебной практикой (семейной медициной) ФПДО СОГМА; тел. (8672) 69-05-79

Поступила 17.08.10 () Бурдули Н.М., Пилиева Н.Г., 2010 удк [616.24-002-085.849.19]-07:616.151.5-074 